\title{
Environment in Indonesian Language Learning
}

\section{Oleh : Afifah Tu Sahada \\ afifahtshd24@gmail.com}

Environmental problems are nothing new. Environmental problems such as forest burning, environmental pollution, hunting of protected animals and plants are problems that have existed in the past, and continue without any resolution. These environmental problems are caused by careless and intensive human activities in natural areas to improve their quality of life. Environmental damage causes a series of problems with natural resources, climate, pollution, food, and the economy, resulting in an imbalance in the environment. One of the efforts to solve this sustainable environmental problem is to instill in the young generation the importance of protecting the environment from an early age. Small things such as not littering, using water as needed, and so on are the first steps that can be done. Instilling a sense of responsibility and awareness of protecting the environment can be done in schools by applying environmental materials in learning. One of the lessons that can be related to environmental material is language learning.

According to Uyar and Ensar (in Ramadhan et al, 2019), using environmental themes in text learning can trigger student interest in learning language and this can have implications for increasing students' knowledge of the environment. Environment-based learning aims to make students participate in protecting the environment. Not seeing the environment as something that can be exploited for personal gain, but as a valuable asset that deserves to be protected for human survival. Therefore, it is important to develop knowledge about the environment, environmental awareness and changes in behavior towards the environment. Environmental education can help students rethink the relationship between humans and the environment, understand the environment, be aware of environmental problems and consider environmental problems related to life (Ramadhan et al, 2019).

According to Obasoro, Oyinloye, and Ilensami (in Ramadhan et al, 2019), students need to have experience in taking initiatives with respect to urgent requirements in the field of global and societal challenges. In line with that, according to Bergman B, G (in Ramadhan et al, 2019), teachers play an important role in teaching environmental education. The teacher can provide environmental material to students so that students can understand the right examples that can be 
found around them. Apart from teachers, students also have an important role in the learning process. Because without a response or action to apply the material provided by the teacher, the purpose of this learning will not be achieved.

Based on the problems described above, the authors conducted research on the importance of the environment in Indonesian language learning. The research was conducted by making 10 statements in the form of a google form questionnaire. The results obtained from this study are as follows. There were 34 people who answered the questions, $82.4 \%$ women, $17.6 \%$ men. Of the 34 people, 26 people were from Padang State University, 3 people from the Muhammadiyah Bukittinggi University, 2 people from the Riau Islamic University, 1 from STKIP Bukittinggi, 2 students.

The first question, in learning Indonesian, environmental material is very important to learn, 58.8\% answered strongly agree, $41.2 \%$ answered agree, $0 \%$ answered strongly disagree, $0 \%$ answered disagree. The second question, the environment is a factor that affects education in schools, 61.8\% answered agree, 38.2\% answered strongly agree, $0 \%$ answered strongly disagree, $0 \%$ answered disagree. The third question, the atmosphere in the school environment must be created optimally to support students to feel comfortable and comfortable learning, $73.5 \%$ answered strongly agree, $26.5 \%$ answered agree, $0 \%$ answered strongly disagreed, $0 \%$ answered disagree. The fourth question, environmental material in Indonesian language learning is related to the use of Indonesian in everyday life, 61.8\% answered agree, 29.4\% answered strongly agree, $8.8 \%$ answered disagree. $0 \%$ answered strongly disagree.

In the fifth question, the advantage of having environmental material in Indonesian language learning is that students can respect and protect the environment well, $61.8 \%$ answered strongly agree, 38.2\% answered agree, $0 \%$ answered strongly disagree, $0 \%$ answered disagree. The sixth question, environmental material can make it easier for students to understand Indonesian material, 70.6\% answered agree, 26.5 answered strongly agreed, 2.9\% answered disagree, $0 \%$ answered strongly disagreed. The seventh question, the environment can develop students' imagination in learning Indonesian, 69.7\% answered agree, 30.3\% answered strongly agree, $0 \%$ answered strongly disagree, $0 \%$ answered disagree. The eighth question, the advantage of having environmental material in Indonesian language learning is that students can respect and protect the environment well, 52.9\% answered strongly agree, $47.1 \%$ answered agree, $0 \%$ answered strongly disagreed, $0 \%$ answered disagree. Furthermore, the ninth question, the 
environment can be used as a discussion in Indonesian language learning, 64.7\% answered agree, $36.3 \%$ answered strongly agree, $0 \%$ answered strongly disagreed, $0 \%$ answered disagree. The last question, namely learning can be used as a theme in Indonesian language learning, 58.8 answered agree, $38.2 \%$ answered strongly agreed, $3 \%$ answered disagree, $0 \%$ answered strongly disagreed.

From the results of the author's research above, it can be concluded that environmental material is very important to be applied in Indonesian language learning. Environmental materials make it easier for students to understand Indonesian material well, add to students 'insight, and can build students' ecological intelligence. Environmental material is material that is closely related to everyday life. Therefore, with environmental material the teacher can easily find relevant examples that make students better understand the material provided, so that it can help teachers imply Indonesian language material.

In (Ramadhan, et al (2019)), a person has the same obligation to protect the environment. To be able to protect the environment requires understanding and knowledge of the environment. The teacher plays an important role in conveying this knowledge to students, because students are the next generation who are tasked with protecting the environment. Environmental education can be integrated into other subjects, one of which is language learning. Integration can be done by using the theme of the environment in text learning. Through the text being studied, students can learn the language and gain environmental knowledge through the content of the text that is read. Based on this, it is important for teachers to have environmental knowledge and environmental care attitudes. If the teacher does not have the knowledge and attitude, language learning becomes less meaningful. Teachers must be able to design language learning by integrating various topics, one of which is environmental education. You can use text related to the environment or use an appropriate learning method. This research can be used as an evaluation material for all parties, especially prospective language teachers to increase their knowledge about environmental education. By increasing this knowledge, it can foster an environmental care attitude and can improve skills in integrating the environment. 


\section{REFERENCE}

Amelia, Rizky,Elfia Sukma,dan Nur Asma. (2015). Pembelajaraan Menulis Laporan Percobaan Dengan Pendekatan Saintifik di Sekolah Dasar. Prosiding Seminar Nasional Jurusan PGSD FIP UNP. Vol.1, No.1

Amin, Irzal, Syahrul R,dan Ermanto. (2013). CERITA RAKYAT PENAMAAN DESA DI KERINCI: Kategori dan Fungsi Sosial Teks. Jurnal Bahasa, Sastra dan Pembelajaran. Vol. 1, No.1

Fitri, Margian Mulya, Syahrul R., Afnita. (2018). Pengaruh Model Discovery Learning Berbantuan Media Gambar Berseri Terhadap Keterampilan Menulis Teks Eksplanasi Siswa Kelas VIII SMP Negeri 25 Padang. Jurnal Pendidikan Bahasa dan Sastra Indonesia, Vol. 1 No. 7

Indriyani, Vivi, M. Zaim, Atmazaki, dan Syahrul Ramadhan. (2019). Literasi Baca Tulis Dan Inovasi Kurikulum Bahasa. KEMBARA: Jurnal Keilmuan Bahasa, Sastra, dan Pengajarannya. Vol. 5, No. 1

Ramadhan, S., Sukma, E., \& Indriyani, V. (2019). Environmental education and disaster mitigation through language learning. IOP Conference Series: Earth and Environmental Science, 314, pp. 1-9.

Sari,Yuliana, Syahrul R, dan Yulianti Rasyid. (2018). Hubungan Antara Keterampilan Membaca Pemahaman Dengan Keterampilan Menulis Teks Laporan Hasil Observasi Siswa Kelas X SMK Negeri 3 Padang. Jurnal Pendidikan Bahasa dan Sastra Indonesia. Vol. 7, No.3

Suardi, Indah Permatasari, Syahrul R, dan Yasnur Asri. (2019). Pemerolehan Bahasa Pertama pada Anak Usia Dini.Jurnal Obsesi : Jurnal Pendidikan Anak Usia Dini. Vol. 3, No.1

Sukma, Elfia, R. Mahyudin, Rahmatina, dan A.Surian. (2019). Problems In Oral Language Teaching In Primary School. Advances in Social Science, Educationand Humanities Research. Vol.301

Sukma, Elfia,Ritawati Mahjuddin, dan Rizky Amelia. (2017). Literacy Media Development in Improving Reading and Writing Skill of Early Class Students in Elementary School Padang Utara Padang. Advances in Social Science, Education and Humanities Research. Vol. 118

Sukma, Elfia,S. Ramadhandan V Indriyani. (2020). Integration of environmental education in elementary schools. Journal of Physics: Conference Series1481 


\section{ATTACHMENT}

Table 1

Questionnaire on Environmental Relations in Indonesian Language Learning

\begin{tabular}{|c|c|c|c|c|c|}
\hline NO & Questions & SS & $\mathbf{S}$ & STJ & TS \\
\hline 1 & $\begin{array}{l}\text { In learning Indonesian, environmental material } \\
\text { is very important to learn. }\end{array}$ & $58,8 \%$ & $41,2 \%$ & $0 \%$ & $0 \%$ \\
\hline 2 & $\begin{array}{l}\text { Environment is a factor that influences education } \\
\text { in schools. }\end{array}$ & $38,2 \%$ & $61,8 \%$ & $0 \%$ & $0 \%$ \\
\hline 3 & $\begin{array}{l}\text { The atmosphere in the school environment must } \\
\text { be created optimally to support students to feel } \\
\text { comfortable and at home to learn. }\end{array}$ & $73,5 \%$ & $26,5 \%$ & $0 \%$ & $0 \%$ \\
\hline 4 & $\begin{array}{l}\text { Environmental materials in Indonesian language } \\
\text { learning are related to the use of Indonesian in } \\
\text { everyday life. }\end{array}$ & $29,4 \%$ & $61,8 \%$ & $8,8 \%$ & $0 \%$ \\
\hline 5 & $\begin{array}{l}\text { The advantage of having environmental material } \\
\text { in Indonesian language learning is that students } \\
\text { can respect and protect the environment well. }\end{array}$ & $61,8 \%$ & $38,2 \%$ & $0 \%$ & $0 \%$ \\
\hline 6 & $\begin{array}{l}\text { Environmental materials can make it easier for } \\
\text { students to understand Indonesian language } \\
\text { material }\end{array}$ & $26,5 \%$ & $70,6 \%$ & $2,9 \%$ & $0 \%$ \\
\hline 7 & $\begin{array}{l}\text { The environment can develop students' } \\
\text { imagination in learning Indonesian. }\end{array}$ & $30,3 \%$ & $69,7 \%$ & $0 \%$ & $0 \%$ \\
\hline 8 & $\begin{array}{l}\text { The advantage of having environmental material } \\
\text { in Indonesian language learning is that students } \\
\text { can respect and protect the environment well. }\end{array}$ & $52,9 \%$ & $47,1 \%$ & $0 \%$ & $0 \%$ \\
\hline 9 & $\begin{array}{l}\text { The environment can be used as a discussion in } \\
\text { learning Indonesian }\end{array}$ & $35,3 \%$ & $64,7 \%$ & $0 \%$ & $0 \%$ \\
\hline 10 & $\begin{array}{l}\text { Learning can be used as a theme in Indonesian } \\
\text { language learning }\end{array}$ & $38,2 \%$ & $58,8 \%$ & $0 \%$ & $0 \%$ \\
\hline
\end{tabular}

Information :

\section{SS: Strongly Agree}

\section{S: Agreed}

STJ: Strongly Disagree

\section{TS: Disagree}

